\title{
Studies on the preparation of antioxidant rich ber (Zizyphusmauritiana Lamk.) powder burfi with coconut sugar as natural sweetener
}

\author{
Sonika Pandey and Amrita Poonia
}

Received: 18 May 2019 / Accepted: 23 November 2019 / Published online: 27 February 2020

(C) Indian Dairy Association (India) 2020

\begin{abstract}
Efforts were made to formulate an antioxidant rich, low sugarburfi. The burfi was enriched with different levels of ber fruit powder $(5 \%, 10 \%$ and $15 \% \mathrm{w} / \mathrm{w})$ and coconut sugar $(28 \% \mathrm{w} / \mathrm{w})$. Sensory scores revealed that burfi with $10 \%$ ber powder had highest overall acceptability. The optimizedber powderburfi was compared with market samples and control burfi and the physicochemical property, antioxidant activity and total phenolic content varied significantly $(\mathrm{P}<0.05)$. Addition of ber powder significantly $(\mathrm{P}<0.05)$ increased iron content, vitamin $\mathrm{C}$ content, antioxidant activity and total phenolic content of optimized burfi followed by the effect of coconut sugar incorporation. The addition of coconut sugar showed significant $(\mathrm{P}<0.05)$ decrease in total sugar content. From the study, it was concluded that the incorporation of berpowder and coconut sugar was a great success and will be helpful for developingother value added dairy confectioneries.
\end{abstract}

Keywords: Antioxidant activity, Ber powder, Coconut sugar, Burfi, Vitamin C

\section{Introduction}

Ber (ZizyphusmauritianaLamk.) is a very old fruit of India. It is also commonly called as Jujube around the world. It is an underutilized fruit in India.Bercomes from the genus Zizyphus of the family Rhamnaceae. The most common cultivated species of

Department of Dairy Science and Food Technology, Institute of Agricultural Sciences, Banaras Hindu University, Varanasi, 221005 Uttar Pradesh, India

Amrita Poonia $(\square)$

Department of Dairy Science and Food Technology, Institute of Agricultural Sciences, Banaras Hindu University, Varanasi, 221005 Uttar Pradesh, India

E-mail: dramritapoonia@gmail.com, Mobile: +919532030058 ber fruit are Zizyphusjujuba and Zizyphusmaurtiana.Zizyphusmauritianais commonly grown all over thenorthwest of India and in the arid parts of South India(Azam et al. 2001; Kumar et al. 2011).It is called as the king of arid zone fruits (Yamadagni 1985).Ber fruits are good source of vitamin $\mathrm{C}$, total phenolics ranging from 19.54 to $99.49 \mathrm{mg} / 100 \mathrm{~g}$ and 172 to $328.6 \mathrm{mgGAE} / 100 \mathrm{~g}$, respectively (Koley et al. 2011). They are rich in mineralslike calcium, phosphorus and iron (Yamadagni1985; Shobaand Bharathi2007). The major phenolics reported are caffeic acid, p-hydroxybenzoic acid,ferulic acid and p-coumaric acid (Tanmay et al. 2011; Memon et al. 2012)which justifies for its significant antioxidant activity (Krishna and Parashar 2012).

Ber fruit is seasonal as well as nutritious, so it needs to be preserved. However, the techniques to be used for preservation must sustain or improve their nutritional quality (Hsu et al. 2003). Out of the numerous processing techniques, spray drying was found to most suitable. It is a technique useful for increasing the shelf life of the fruit. The spray drying process can form good quality powder with less water activity so that it can be easy to store and transport. The most common carrier agent used for fruit juices are maltodextrins (Cano-Chuca et al. 2005).

Coconut sugar is a natural sweetener with wonderful taste and nutritional content. It is however, less known to people. Coconut sap is converted to coconut sugar and is becoming popular worldwide because it is natural, minimal processed and healthy. One of the most important health claims is its glycemic index (GI). Foods with low GI are vital for diabetes, obesity, heart disease and hypertension (Jenkins et al. 1981). A research published that the GI of coconut sap sugar was reported to be 35, i.e. in low category (Trinidad et al. 2010). Coconut sugar consists of minerals such as iron, zinc, calcium, phosphorus, magnesium and potassium, accompanied bysome short chain fatty acids. It is also good in vitamins such as vitamin $\mathrm{C}$ and vitamin $\mathrm{B}$ complex, polyphenols, antioxidants, dietary fibre and inulin (Hebbar et al. 2015; Secretaria et al. 2007).

Burfi is one of the most popular khoa based milk product appreciated all over India. It is prepared by evaporating milk in an open pan to obtain a semi-solid product called khoa(BIS 1970). 
There are many types of burfi present in market viz. simple, mawa, fruit, cashewnut, almond, besan, khajoor etc. Due to its attractiveness and wide acceptancethroughout India, many forms of burfi with numerous ingredients and flavours have been developed. Inventive researches are being done with burfi like herbal burfi prepared by Goyal and Shamsher (2015), Prasad et al. (2017), burfi with essential oil formulated by Prasad et al. (2018) and aloe-verapeda by Srikanth et al. (2017).

Keeping the above points in mind, the study was aimed to formulate a value- added product with high nutritional content, good antioxidant properties and low sugar content. Looking to the functional, nutritional and low sugar aspect, ber fruit powder and coconut sugar was found to be suitable for incorporation in milk based product, burfi. Hence, our present investigation was undertaken with the objective of evaluating the best ber powder burfi and the effect of incorporation of spray dried ber powder and coconut sugar on various physicochemical and antioxidant attributes of burfi samples.

\section{Materials and Methods}

\section{Materials}

Full cream milk and coconut sugar were purchased from the local market of Varanasi, India. Ber fruits were acquired from horticultural farm of Banaras Hindu University, Varanasi and the cultivar was identified by the experts of the Department of Horticulture. They identified the cultivar as Banarsi Karaka. All chemicals were obtained from Hi-media Laboratories Limited, Mumbai, India.

\section{Production of ber fruit powder}

The flowchart of the whole process is given in Figure 1. The process conditions (Inlet air temperature and maltodextrin concentration) were optimized by Response Surface Methodology using Minitab 17.1.0 software to get the finest quality ofber fruit powder. The slurry was spray dried in a labscale spray dryer (Model: Spray Mate - JISL Instruments Private Limited, Mumbai, India) with an inlet air temperature of $166.21^{\circ} \mathrm{C}$, outlet air temperature of $80^{\circ} \mathrm{C}$, feed rate of $18 \mathrm{rpm}$, air pressure of $2 \mathrm{~kg} / \mathrm{cm}^{2}$ and aspirator speed of $1250 \mathrm{rpm}$. The spray dried fruit juice powder was collected at the bottom of the cyclone jar. The samples were then transferred to aluminium laminated polyethylene packages of size $12 \mathrm{~cm}$ x $9 \mathrm{~cm}$ and sealed immediately.

\section{Preparation of ber burfi}

The buffalo milk was standardized to $6 \%$ fat and 9\% SNF. Milk was concentrated in an open karahi (pan) at boiling temperature with continuous stirring and scraping till the final stage of semisolid consistency (khoa) is reached. The coconut sugar was added (a) 28\% in the burfi. The temperature was further lowered to 88-90
${ }^{\circ} \mathrm{C}$ and selected levels of spray dried ber powder $(0,5,10$ and $15 \%$ ) were added. Finally, this mixture was heated at low temperature with slow stirring till the desired consistency of ber powderburfi was obtained. This mixture was then spread uniformly in a tray and allowed to cool. After it has been settled, pieces of rectangular blocks were cut by knives.

The proportions of ingredients produced by the levels of ber powder addition, were considered as treatments as given below.

Treatment details:

$\mathrm{T}_{0}(\mathrm{Control})=0 \%$ ber powder $+100 \%$ of khoa by weight

$\mathrm{T}_{1}=5 \%$ ber powder $+95 \%$ of khoa by weight

$\mathrm{T}_{2}=10 \%$ ber powder $+90 \%$ of khoa by weight

$\mathrm{T}_{3}=15 \%$ ber powder $+85 \%$ of khoa by weight

\section{Sensory evaluation}

The sensory attributes of ber powder burfiwere analyzed for colour and appearance, body and texture, flavour, sweetness and overall acceptability by a semi-trained panel of judges consisting of ten members selected from the Centre of Food Science and Technology, Institute of Agricultural Sciences, Banaras Hindu University, Varanasi, India.To minimize the variances, the panellists were made familiar with the quality attributes and the flaws generally associated with burfi under study. The attributes were evaluated on the basis of 9-point hedonic scale.

\section{Colouranalysis}

The colour of ber powder burfi was measured in terms of the CIE $L^{*}, a^{*}, b^{*}$ values using Color Flex EZ spectrophotometer. L* represents the lightness ( $\mathrm{L}^{*}=0$ for black and $\mathrm{L}^{*}=100$ for white), $\mathrm{a}^{*}$ indicates red $(+)$ to green (") axis, and b* represents yellow $(+)$ to blue (") axis (Duangmal et al. 2008).

\section{Texture analysis}

Texture profile analysis on ber powder burfi samples was performed by using the texture analyser TA.XT plus, Exponent Lite (Stable Micro Systems, Surrey, UK). A 75mm compression platen was used under $50 \mathrm{~kg}$ load cell. Burfi samples were cut into $1 \mathrm{~cm}^{3}$ cubes and subjected toa dual bite compression force by probe upto a $5.00 \mathrm{~mm}$ distance at $1.0 \mathrm{~mm} / \mathrm{s}$ test speed.

\section{Proximate analysis}

Moisture, fat, protein, ash, acidity, total solids, total sugar, iron and vitamin $\mathrm{C}$ were analyzed in ber powder burfi sample and spray dried ber fruit powder by following the AOAC (2000) methods. 


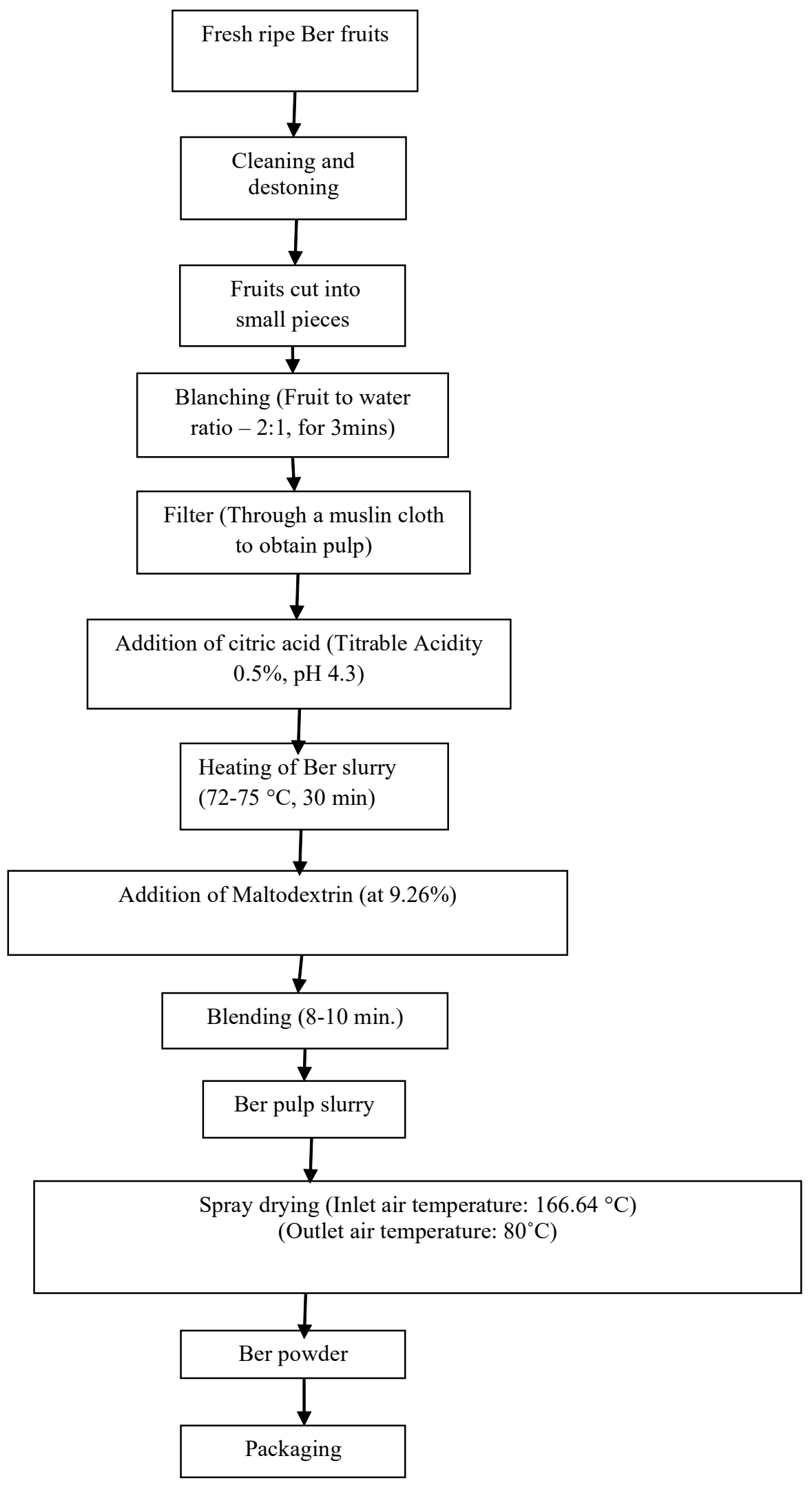

Fig. 1 Process flowchart of ber fruit powder production 


\section{Free radical scavenging activity}

The free radical scavenging activity was determined by using DPPH assay (Brand-Williams et al. 1995). A $3.9 \mathrm{~mL}$ aliquot of a $0.0634 \mathrm{mM}$ of DPPH solution, in methanol (95\%) was added to 0.1 $\mathrm{mL}$ of methanolic burfi sample extract or ber powder sample extract and shaken. The samples were kept in the dark room for 30 minutes after which absorbance was recorded at $515 \mathrm{~nm}$. The percentage inhibition of DPPH was calculated by the following formula: \%inhibition $=100 \times\left(A_{0}-A\right) / A_{0}$ where $A_{0}$ was the control absorbance at $515 \mathrm{~nm}$ and $\mathrm{A}$ was the final absorbance of the sample extract at $515 \mathrm{~nm}$. Methanol (95\%) was used as a blank.

\section{Total phenolic content}

Total phenolic content was evaluated byFolin-Ciocalteu method defined by Liu et al. (2008) with some modifications. $60 \mu \mathrm{L}$ of burfi extract or ber powder extract , $300 \mu \mathrm{L}$ of FolinCiocalteaureagent and after 3 minutes $750 \mu \mathrm{L}$ of $20 \%$ sodium carbonate in water were added in $4.75 \mathrm{~mL}$ of water. The mixture was kept for about 30 minutes. The absorbance was then recorded at $765 \mathrm{~nm}$. For blank preparation, $60 \mu \mathrm{L}$ of distilled water was taken instead of sample. Total phenol content of sample was calculated using equation of standard curve and the results are expressed as $\mathrm{mg}$ of GAE.

\section{Statistical analysis}

The data acquired from various experiments were recorded as mean \pm standard deviation (SD). Data was statistically analyzed using one way analysis of variance (ANOVA) followed by Tukey's comparison test to find the significant differences among the mean values at $95 \%$ level of confidence using Minitab software ver. 17.0.1.

\section{Results and Discussion}

The results of sensory attributes, colour values and instrumental textural profile were discussed for different burfi samples $\left(\mathrm{T}_{0}, \mathrm{~T}_{1}\right.$, $\mathrm{T}_{2}$ and $\mathrm{T}_{3}$ ). The spray dried ber powder was analyzed for proximate parameters, antioxidant activity and total phenolic content (Table 1) which will further be used for the comparative analysis.

The optimized ber powder burfi was determined on the basis of sensory evaluation. The optimized burfi was then compared with market and control burfi (Table 5). The means were compared using Tukey's Test with confidence level of $95 \%$. The differences were indicated as superscripts.

\section{Sensory attributes}

The sensory mean score for colour and appearance of ber powder burfi varied from 7.35 to 8.57 , body and texture from 7.23 to 8.66 , flavour from 7.21 to 8.83 , sweetness from 7.31 to 8.48 and overall acceptability from 7.41 to 8.63 . It is evident from the data presented in Table 2 that most of the samples prepared are significantly different $(\mathrm{P}<0.05)$ from the control sample. The overall acceptability score for the ber powder burfi prepared with $10 \%$ ber powder was found to be most satisfactory by the panelist. This optimized burfi was finally used for further analysis in the study. This shows that ber powder incorporation improved the sensory properties of the burfi samples up to $10 \%$ level, but further increase led to the reduction of sensory score. These results are in similarity with Bankar et al. (2013) and Khapre et al. (2015), who studied the preparation of pineapple burfi and fig fruit powder burfi respectively. Kim and Lee (2012) worked on jujube (ber) powder muffins and recommended $10 \%$ level of jujube powder with respect to overall preference score.

\section{Colour values}

The lightness, redness and yellowness values of ber powder burfi are presented in Table 3. Lightness index ranged from 44.24 to 47.34 which is a low value. This could be due to the addition of coconut sugar which has imparted brown colour to burfi. Lightness value decreased in significant manner $(\mathrm{P}<0.05)$ and was found lowest for $15 \%$ level of incorporation due to higher percentage of ber powder. The redness-greenness index ranged from 7.28 to 8.07 and increased significantly with increased levels of powder. They ellowness-blueness index ranged from 16.25 to17.63 and decreased significantly. Similar results were reported by Tanuja et al. (2017) in apple pomace incorporated burfi andKim and Lee (2012) in jujube powder muffins.

\section{Instrumental texture parameters}

The measured textural parameters of the ber powder burfi samples are given in Table 4. The value of hardness ranged from 5292.76 to $7018.78 \mathrm{~g}$, adhesiveness -5.05 to $-80.03 \mathrm{~g}$.sec, springiness 0.23 to 0.35 , cohesiveness from 0.26 to 0.34 , gumminess from 1438.62 to 2205.97 and chewiness from 365.05 to 764.71 .

Hardness is the most assessed characteristic in determining the texture of burfi. Addition of ber powder increased the hardness of burfi significantly $(\mathrm{P}<0.05)$. This may be due to the lower moisture content of ber powder. The result here is in agreement with walnut powder burfi (Satav et al. 2014). Similar findings were reported byJha et al.(2014) in lalpeda.

The sensory stickiness is due to adhesiveness. The adhesiveness of ber powder burfidecreased significantly $(\mathrm{P}<0.05)$ because of low moisture. The result was similar to that of lalpedareported by Jha et al. (2014).Rasane et al. (2012) reported variation in adhesiveness of market samples of burfi due to different sugar levels. A higher adhesiveness value is due to higher moisture content in peda (Londhe and Pal 2008). Cohesiveness and springiness were not much affected but showed a decreasing trend. It may be attributed with the loss of moisture content and increasing totalsolids. Gupta et al. (1990) reported that cohesiveness of khoa decreased with increasing total solids. 
Gumminess and chewiness also decreased significantly $(\mathrm{P}<0.05)$. The textural parameters were greatly influenced by the moisture content and total solids. Similar findings were reported by Tanuja et al. (2017) in apple pomace burfi.

\section{Effect of incorporating ber powder and coconut sugar on the physicochemical parameters of burfi and its comparison with the market burfi}

The moisture content of burfi samples varied from 17.65 to $21.37 \%$ (Table 5) and decreased significantly $(\mathrm{P}<0.05)$. The optimized burfi had the lowest moisture content of $17.65 \%$. This was because of the addition of spray dried ber powder, which had less moisture (Table 1).Results are in similarity with Kim and Lee (2012). The moisture content of the control burfi is also less than market burfi, this may be due to the fiber content of coconut sugar (Trinidad et al. 2010).

The fat content of burfi samples ranged from 19.46 to $22.60 \%$ was not much influenced by the coconut sugar addition. But it is lowest in optimized burfi i.e. $19.46 \%$, may be because of ber powder having very minimum fat content and also due to khoa percentage has decreased.

The protein content, titratable acidity and ash content were not much affected by addition of coconut sugar powder and ranged from 13.20 to $15.48 \%, 0.24$ to $0.36 \%$ and 2.70 to $3.14 \%$ respectively. However titratable acidity is affected by the ber powder addition and is highest in case of optimized burfi due to the acidity ofber fruit powder (Table 1). Also the protein content and ash content decreased in optimized burfidue to low percentage of khoa. Some results here are in agreement with Bankar et al.(2013) and Goyal and Shamsher (2015) while they worked on pineapple burfi and herbal burfi, respectively.

Total solids is significantly $(\mathrm{P}<0.05)$ influenced by addition of coconut sugar due to its minerals and fiber content (Philippine Coconut Authority) (Trinidad et al. 2010). It is highest for the control burfi, $84.25 \%$ and lowest for the optimized burfi, $80.29 \%$. The result here is in similarity with probiotic ice cream which

Table 1 Physicochemical and antioxidant composition of spray dried ber powder

\begin{tabular}{lc}
\hline Parameters & Composition \\
\hline Moisture (\%) & $4.85 \pm 0.05$ \\
Fat (\%) & $0.06 \pm 0.06$ \\
Ash (\%) & $0.98 \pm 0.02$ \\
Acidity (\% citric acid) & $0.83 \pm 0.05$ \\
Total Sugar (\%) & $24.00 \pm 2.00$ \\
Iron (mg/100g) & $12.80 \pm 0.08$ \\
Vitamin C (mg/100g) & $91.62 \pm 0.32$ \\
DPPH activity (\%) & $90.50 \pm 2.26$ \\
Total phenolic content (mgGAE/100g) & $1133.33 \pm 2.86$ \\
\hline
\end{tabular}

Values are mean \pm standard deviation $(\mathrm{n}=3)$

Table 2 Mean sensory score for burfi prepared by different levels of ber powder

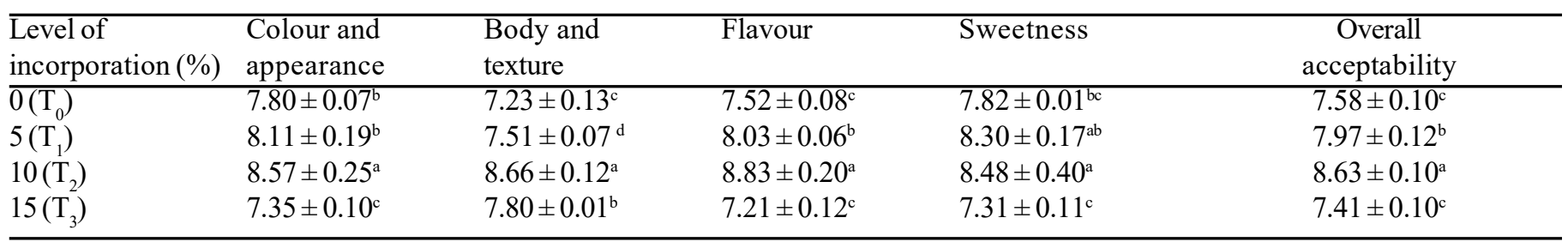

Values are mean \pm standard deviation $(n=3)$

Means in the same column that do not share a letter differ significantly $(\mathrm{P}<0.05)$

Table 3 Colour values for burfi prepared by different levels of ber powder

\begin{tabular}{llll}
\hline Level of incorporation $(\%)$ & $\mathrm{L}^{*}$ & $\mathrm{a}^{*}$ & $\mathrm{~b}^{*}$ \\
\hline $0\left(\mathrm{~T}_{0}\right)$ & $47.34 \pm 0.10^{\mathrm{a}}$ & $7.28 \pm 0.08^{\mathrm{c}}$ & $17.63 \pm 0.08^{\mathrm{a}}$ \\
$5\left(\mathrm{~T}_{1}\right)$ & $47.09 \pm 0.02^{\mathrm{b}}$ & $7.47 \pm 0.08^{\mathrm{c}}$ & $17.24 \pm 0.12^{\mathrm{b}}$ \\
$10\left(\mathrm{~T}_{2}\right)$ & $44.38 \pm 0.01^{\mathrm{c}}$ & $7.80 \pm 0.10^{\mathrm{b}}$ & $16.25 \pm 0.02^{\mathrm{c}}$ \\
$15\left(\mathrm{~T}_{3}\right)$ & $44.24 \pm 0.04^{\mathrm{c}}$ & $8.07 \pm 0.03^{\mathrm{a}}$ & $16.35 \pm 0.05^{\mathrm{c}}$ \\
\hline
\end{tabular}

Values are mean \pm standard deviation $(\mathrm{n}=3)$

Means in the same column that do not share a letter differ significantly $(\mathrm{P}<0.05)$ 
Table 4 Instrumental texture profile for burfi prepared by different levels of ber powder

\begin{tabular}{lllllll}
\hline $\begin{array}{l}\text { Level of } \\
\text { incorporation }(\%)\end{array}$ & Hardness (g) & Adhesiveness & $\begin{array}{l}\text { Springiness } \\
(\mathrm{g} . \mathrm{sec})\end{array}$ & Cohesiveness & Gumminess & Chewiness \\
\hline $0\left(\mathrm{~T}_{0}\right)$ & $5292.76 \pm 2.01^{\mathrm{d}}$ & $-30.50 \pm 0.25^{\mathrm{b}}$ & $0.25 \pm 0.03^{\mathrm{b}}$ & $0.27 \pm 0.02^{\mathrm{b}}$ & $1438.62 \pm 2.01^{\mathrm{d}}$ & $365.05 \pm 0.05^{\mathrm{d}}$ \\
$5\left(\mathrm{~T}_{1}\right)$ & $6546.72 \pm 3.00^{\mathrm{c}}$ & $-5.05 \pm 0.10^{\mathrm{d}}$ & $0.35 \pm 0.01^{\mathrm{a}}$ & $0.34 \pm 0.03^{\mathrm{a}}$ & $2205.97 \pm 2.01^{\mathrm{a}}$ & $764.71 \pm 0.03^{\mathrm{a}}$ \\
$10\left(\mathrm{~T}_{2}\right)$ & $6812.11 \pm 2.11^{\mathrm{b}}$ & $-17.88 \pm 0.31^{\mathrm{c}}$ & $0.32 \pm 0.06^{\mathrm{ab}}$ & $0.29 \pm 0.01^{\mathrm{ab}}$ & $1987.20 \pm 1.02^{\mathrm{b}}$ & $635.27 \pm 0.07^{\mathrm{b}}$ \\
$15\left(\mathrm{~T}_{3}\right)$ & $7018.78 \pm 3.00^{\mathrm{a}}$ & $-80.03 \pm 0.97^{\mathrm{a}}$ & $0.23 \pm 0.02^{\mathrm{b}}$ & $0.26 \pm 0.01^{\mathrm{b}}$ & $1851.94 \pm 0.98^{\mathrm{c}}$ & $425.52 \pm 0.31^{\mathrm{c}}$ \\
\hline
\end{tabular}

Values are mean \pm standard deviation $(n=3)$

Means in the same column that do not share a letter differ significantly $(\mathrm{P}<0.05)$

Table 5 Physicochemical and antioxidant parameters of different burfi samples

\begin{tabular}{lllc}
\hline Parameters & Market burfi & Control burfi $\left(\mathrm{T}_{0}\right)$ & Optimized burfi $\left(\mathrm{T}_{2}\right)$ \\
\hline Moisture(\%) & $21.37 \pm 0.06^{\mathrm{a}}$ & $19.42 \pm 0.04^{\mathrm{b}}$ & $17.65 \pm 0.01^{\mathrm{c}}$ \\
Fat (\%) & $21.50 \pm 0.02^{\mathrm{b}}$ & $22.60 \pm 0.01^{\mathrm{a}}$ & $19.46 \pm 0.01^{\mathrm{c}}$ \\
Protein (\%) & $15.13 \pm 0.22^{\mathrm{a}}$ & $15.48 \pm 0.02^{\mathrm{a}}$ & $13.20 \pm 0.17^{\mathrm{b}}$ \\
Acidity (\% lactic acid) & $0.24 \pm 0.02^{\mathrm{b}}$ & $0.25 \pm 0.006^{\mathrm{b}}$ & $0.36 \pm 0.01^{\mathrm{a}}$ \\
Ash (\%) & $3.14 \pm 0.03^{\mathrm{a}}$ & $3.10 \pm 0.10^{\mathrm{a}}$ & $2.70 \pm 0.20^{\mathrm{b}}$ \\
Total solids (\%) & $82.25 \pm 0.01^{\mathrm{b}}$ & $84.25 \pm 0.05^{\mathrm{a}}$ & $80.29 \pm 0.02^{\mathrm{c}}$ \\
Total sugar (\%) & $54.13 \pm 0.03^{\mathrm{a}}$ & $36.04 \pm 0.19^{\mathrm{c}}$ & $36.86 \pm 0.02^{\mathrm{b}}$ \\
Iron (mg/100g) & $0.00 \pm 0.00^{\mathrm{c}}$ & $2.55 \pm 0.04^{\mathrm{b}}$ & $5.50 \pm 0.05^{\mathrm{a}}$ \\
Vitamin C (mg/100g) & $0.00 \pm 0.03^{\mathrm{c}}$ & $6.80 \pm 0.11^{\mathrm{b}}$ & $18.98 \pm 0.19^{\mathrm{a}}$ \\
DPPH activity (\%) & $6.07 \pm 0.35^{\mathrm{c}}$ & $15.46 \pm 0.78^{\mathrm{b}}$ & $40.88 \pm 0.56^{\mathrm{a}}$ \\
Total phenolic content & $110.27 \pm 1.30^{\mathrm{c}}$ & $285.32 \pm 2.01^{\mathrm{b}}$ & $406.72 \pm 2.09^{\mathrm{a}}$ \\
(mgGAE/100g) & & & \\
\hline
\end{tabular}

Values are mean \pm standard deviation $(n=3)$

Means in the same row that do not share a letter differ significantly $(\mathrm{P}<0.05)$

showed increased total solids when the concentration of coconut sugar was increased as studied by Low et al. (2015).

Total sugar concentration showed a higher significant $(\mathrm{P}<0.05)$ difference among the three burfi samples. Total sugar was highest for market burfi, $54.13 \%$ and lowest for the control burfi, 36.04\%. The addition of coconut sugar has pointedly contributed to the above findings. It is due to reason that coconut sugar has a total sugar concentration of $23.77-71.89 \%$ and sucrose of $49.41 \%$ as studied by Phaichamnanet al.(2010) and Somawiharja et al.(2018), respectively which is relatively lesser than the refined sugar which has a sucrose level of $99.80 \%$ (USDA). Iron content is also significantly affected by the addition of both coconut powder and ber powder (Table 1) because both are iron rich, therefore enriching burfi which does not have iron in it. The iron concentration ranged from 0.00 to $5.50 \mathrm{mg} / 100 \mathrm{~g}$.

The vitamin C content ranged from 0 to $18.98 \mathrm{mg} / 100 \mathrm{~g}$. Both coconut sugar and ber powder have contributed significantly $(\mathrm{P}<0.05)$ to the highest content of vitamin $\mathrm{C}$ in optimized burfi.

The DPPH free radical scavenging activity was also influenced by coconut sugar and ber powder. It ranged from 6.07 to $40.88 \%$. The ber powder incorporation had the maximum significant $(\mathrm{P}<0.05)$ effect on the free radical capacity of optimized burfi. Ber fruit powder has free radical (DPPH) capacity of $90.50 \%$ as shown in Table 1. These findings are in resemblance with Kavitha and Kuna (2014) who formulated ber RTS beverage. Likewise,ber juice vinegar was formed and due to its high antioxidant activity it was called as functional vinegar (Vithlani and Patel 2010).

Coconut sugar also influenced the free radical capacity significantly $(\mathrm{P}<0.05)$. The results in the current findings are in close similarity with Low et al. (2015) who studied the antioxidant activity of probiotic ice cream by incorporating different levels of cane sugar and coconut palm sugar.

Total phenolic content of optimized burfi was significantly higher $(\mathrm{P}<0.05)$ as compared to market burfi and control burfi i.e. 406.72, 110.27 and $285.32 \mathrm{mgGAE} / 100 \mathrm{~g}$, respectively. Both coconut sugar and ber powder have influenced phenolic content. The total phenolic content and antioxidant activity are related to each other as they have hydroxyl group in their chemical structure (Tawaha et al. 2007). Results here are comparable with Victor and Orsat (2018) who studied that palm sugar has appreciable amount of antioxidant activity and total phenolic content. Also, Koley et al. (2011) reported that 12 commercial cultivars of $Z$. mauritiana are good source of ascorbic acid, total phenolics, flavonoids, and total antioxidant activity. Further, it was also observed that even though no fruit powder or polyphenolic substrate was added to market burfi, yet it showed some amount of anti-oxidative activity, viz., total phenolic content of $110.27 \mathrm{mgGAE} / 100 \mathrm{~g}$ and DPPH inhibition of $6.07 \%$. This could be due to association with free 
sulphahydral groups and maillard browning products which were formed during preparation of khoa (Prasad et al. 2017). Similarly, Oh et al. (2013) reported maillard browning products have DPPH free radical scavenging activity.

\section{Conclusions}

Ber fruit powder is rich in vitamin $\mathrm{C}$ and has good antioxidant properties. With the results mentioned above, it can be concluded that the ber powder burfi with $10 \%$ level of ber powder and $28 \%$ coconut sugar was considered best. Both coconut sugar and ber powder have significantly enhanced the physicochemical properties, free radical scavenging activity and total phenolic content of burfi. Therefore, with such an outcome our attempt to formulate a value-added burfi with good antioxidant property and low sugar has been successfully attained.

\section{References}

AOAC (2000) Methods of analysis, 17th edn. Association of Official Analytical Chemists Washington, USA

Azam-Ali S, Bonkoungou E, Bowe C, DeKock C, Godara A and Williams JT (2001) Fruits for the future 2 (revised edition) Ber and other jujubes. International Centre for Underutilised Crops, University of Southampton, Southampton, SO17 1BJ, UK.

Bankar S N, Barbind RP, Korake RL, Gaikwad SV, Bhutkar SS (2013) Studies on preparation of pineapple burfi. Asian J Dairy Food Res 32: $40-45$.

BIS (1970) Indian standard specifications of burfi. IS: 5520-1970.Bureau of Indian Standards, New Delhi.

Brand-Williams W, Cuvelier ME, Berset C (1995) Use of freeradical method to evaluate antioxidant activity. LWT- Food Sci Technol 28: 25-30

Cano-Chauca M, Stringheta PC, Ramos AM, Cal-Vidal J (2005) Effect of the carriers on the microstructure of mango powder obtained by spray drying and its functional characterization. Innovation Food Sci Emerg Technol 6: 420-428

Duangmal K, Saicheua B, Sueeprasan S (2008) Colour evaluationof freezedried roselle extract as a natural food colorant in a modelsystem of a drink. LWT- Food Sci Technol 41:1437-1445

Goyal SK, Samsher (2015) Studies on quality attributes of herbal burfi. South Asian J Food Technol Envir 1: 46-51

Gupta SK, Patil GR, Patel AA, Garg F C and Rajorhia GS (1990) Instrontexture profile parameters of khoa as influenced by composition. J Food Sci Technol 27: 209-213

Hebbar KB, Arivalagan M, Manikantan MR, Mathew AC, Thamban C, Thomas GV, Chowdappa P(2015) Coconut inflorescence sap and its value addition as sugar-collection techniques, yield, properties and market perspective. Curr Sci 109: 1411-1417

Hsu C, Chen W, Weng Y, Tseng C (2003) Chemical composition, physical properties, and antioxidant activities of yam flours as affected by different drying methods. Food Chem 83: 85-92

Jenkins DJA, Wolever TMS, Taylor RH (1981) Glycemic index of foods: A physiological basis for carbohydrate exchange. Am J Clin Nutr 34: 362-366.

Jha A, Kumar A, Jain P, Om H, Singh R and Bunkar DS (2014) Physicochemical and sensory changes during the storage of lalpeda. J Food Sci Technol 51: 1173-1178

Kavitha C, Kuna A (2014) Effect of processing on antioxidant properties of ber (Zizyphusmauritiana) fruit. Int J Sci Res 3: 2019-2025
Khapre AP, Satwadhar PN and Syed HM (2015) Studies on processing technology and cost estimation of fig (Ficuscarica L.) fruit powder enriched Burfi (Indian cookie).ý J Appl Nat Sci 7: 621-624.

Kim EJ, Lee JH (2012) Qualities of muffins made with jujube powder. Korean J Food Nutr 41: 1792-1797

Koley TK, Charanjit K, Shweta N, Shweta W,Seema J, Sarika (2011) Antioxidant Activity and phenolic content in genotypes of Indian jujube(ZyziphusmauritianaLamk.). Arab J Chem 9: 1044-1052.

Krishna H, Parashar A (2012)Phytochemical constituents and antioxidant activities of some Indian jujube (Ziziphusmauritiana Lamk.) cultivars. J Food Biochem 37: 571-577

Kumar S, Yadav P, Jain V, Malhotra SP (2011) Evaluation of oxidative stress and antioxidative system in ber (Ziziphusmauritiana L.) fruits during storage. J Food Biochem 35: 1434-1442

Liu X, Cui C, Zhao M, Wang J, Luo W, Yang B, Jiang Yv(2008) Identification of phenolics in the fruit of emblica (Phyllanthusemblica L.) and their antioxidant activities. Food Chem 109: 909-915

Londhe GK, Pal D (2008) Studies on the quality evaluation of market samples of brown peda. Indian J Dairy Sci 61: 347-352

Low RHP, Baba AS, Aboulfazli F (2015) Effects of different levels of refined cane sugar and unrefined coconut palm sugar on the survivability of Lactobacillus acidophilus in probiotic ice cream and its sensory and antioxidant properties. Food Sci Technol Res 21: 857-862.

Memon A, Memon N, Luthria D, Pitafi A, Bhanger M (2012) Phenolic compounds and seed oil composition of Ziziphusmauritiana L. fruit. Pol J Food Nutr Sci 62: 15-21

Oh NS, Lee HA, Lee JY, Joung JY, Lee KB, Kim Y, Lee K W, Kim S $\mathrm{H}(2013)$ The dual effects of Maillard reaction and enzymatic hydrolysis on theantioxidant activity of milk proteins. J Dairy Sci 96: 4899-4911

Phaichamnan M, Posri W, Meenune M (2010) Quality profile of palm sugar concentrate produced in Songkhlaprovince, Thailand. Int Food Res J 17: 425-432

Philippine Coconut Authority Plant and Tissue Analysis Laboratory Coconuts Today, November 2004, vol.19.

Prasad W, Khamrui K, Mandal S, Badola R (2017) Anti-oxidative, physicochemical and sensory attributes of burfi affected by incorporation of different herbs and its comparison with synthetic anti-oxidant (BHA). J Food SciTechnol 54: 3802-3809.

Prasad W, Khamrui K, Mandal S, Badola R (2018) Effect of combination of essential oils onphysicochemical and sensorial attributes of burfi in comparison with individual essential oil and BHA. Int J Dairy Technol 71: 810-819

Rasane P, Arvind, Jha A (2012) Sensory and textural profile analysis of burfisample manufactured in Varanasi. J Dairy Foods Home Sci 31: 168-172

Satav YL, Narwade SG, Kadam RP, Hashmi SI (2014) Effect of walnut powder incorporation on sensorial, nutritional and textural quality profile of burfi. Asian J Anim Sci 9: 129-133

Sawhney IK, Patil GR, Kumar B, Grover S (1997) Influence of water activity adjustment on sorption characteristics, acceptability and microbial stability of khoa. J Food Sci Technol 34: 123-127

Secretaria MI, Ebun RM, Magat SS (2007) Production of natural and nutritious sugar, honey, juice and vinegar from coconut sap. Cocoinfo Int14: 18-21

Shoba D, Bharati P (2007) Value addition to ber (ZizyphusmauritianaLamk.) through preparation ofpickle. Karnataka J Agric Sci 20: 353-355

Somawiharja Y, Purnomo H, Wonohadidjojo DM, Kartikawati M and Suniati F R T(2018) Indigenous technology of tapping, collecting and 
processing of coconut (Cocosnucifera) sap and its quality in Blitar Regency, East Java, Indonesia

Srikanth K, Kartikeyan S, Kalla AM (2017) Storage studies of aloe vera juice incorporated peda. Int J Food Fermentation Technol 7: 231239

Tanmay KK, Shweta W, Prerna N, Awasthi OP, Charanjit K (2011)Nutraceutical composition ofZizyphusmauritianaLamk (Indian ber): effect of enzyme-assisted processing. Int J Food Sci Nutr 62: 276-279

Tanuja, Pathak V, Goswami M (2017) Development of quality evaluation of apple pomace incorporated burfi. Indian J Dairy Sci 70: 162-166

Tawaha K, Alali FQ, Gharaibeh M, Mohammad M, El-Elimat T (2007) Antioxidant activity and total phenolic content of selected Jordanian plant species. Food Chem 104: 1372-1378
Trinidad TP, Mallillin AC, Sagum RS, Encabo RR(2010) Glycemic index of commonly consumedcarbohydrate foods in the Philippines. J Funct Foods 2: 271-274

Victor I, Orsat V (2018) Characterization of Arengapinnata (palm) sugar. Sugar Technol 20: 105-109

Vithlani VA, Patel HV (2010) Production of functional vinegar from Indian jujube (Zizyphusmauritiana) and its antioxidant properties. $\mathrm{J}$ Food Techol 8:143-149

Yamadagni R (1985) Ber In-Fruits of India. Tropical and subtropical. Ed. Bose, T.K. Naya Prakash, Calcutta, India 